\title{
UGT1A1 POLYMORPHISMS AS A PHARMACOGENETIC MARKERS FOR PREDICTION OF IRINOTECAN-INDUCED TOXICITIES IN METASTATIC COLORECTAL CANCER
}

\author{
PETRA VUKOVIĆ ${ }^{1,6}$, TAMARA ŽIGMAN ${ }^{2,6}$, MIRTA ZEKAN VUČETIĆc ${ }^{5,6}$, \\ SNJEŽANA RAMIĆ ${ }^{3,6}$, IVA KIRAC ${ }^{4,6}$
}

${ }^{1}$ Division of Radiotherapy and Medical Oncology, University Hospital for Tumors,

Sestre milosrdnice University Hospital Center, Zagreb, Croatia;

${ }^{2}$ Department of Paediatrics, Division for Medical Genetics and Inherited Metabolic Diseases, University Hospital Centre Zagreb, Zagreb, Croatia;

${ }^{3}$ Department of Oncological Pathology, 'Ljudevit Jurak' University Department of Pathology,

Sestre milosrdnice University Hospital Center, Zagreb, Croatia;

${ }^{4}$ Department of Surgical Oncology, University Hospital for Tumors,

Sestre milosrdnice University Hospital Center, Zagreb, Croatia;

${ }^{5}$ Division of Diagnostic and Interventional Radiology, Department of Oncological Radiology, University Hospital for Tumors, Sestre milosrdnice University Hospital Center, Zagreb, Croatia;

${ }^{6}$ Genetic Counselling Unit, University Hospital for Tumors, Sestre milosrdnice University Hospital Center, Zagreb, Croatia

\begin{abstract}
Summary
This paper aimed to review the current status of UGT1A1 polymorphisms as a pharmacogenetic marker for prediction of irinotecan-induced toxicities in metastatic colorectal cancer. Deficiencies in the activity uridine diphosphate glucuronosyltransferases (UGT) are mostly due to gene polymorphisms and can lead to increased exposure to irinotecan and its active metabolite causing severe, sometimes life-threatening treatment-related toxicities. Although data suggest that UGT1A1 polymorphisms, especially homozygous (UGT1A1*28/*28, UGT1A1*6/*6) are related to severe irinotecan toxicity and some guidelines highlighted the importance of upfront UGT1A1 genotyping in order to give safer irinotecan dose, UGT1A1 genotyping is currently not being routinely performed in the daily clinical practice. It is important to note that genetic polymorphisms of UGT1A1 show ethnic differences and it is suggested that Caucasian patients should be upfront screened for UGT1A1*28 and Asian patients for UGT1A1* 6 as these polymorphisms are common genetic variation in these populations. Data regarding the association of UGT1A1 polymorphisms and treatment response and survival are conflicting.

Nevertheless, it is important to think about other genetic variations in the context of chemotherapy-induced toxicities, especially dihydropyrimidine dehydrogenase deficiency (DYPD).

In conclusion, UGT1A1 polymorphisms are pharmacogenetic markers which can be used for stratification of patients who are at higher risk of irinotecan-induced toxicities to allow preventive dose reduction to reduce potential toxicities.
\end{abstract}

KEYWORDS: uridine diphosphate glucuronosyltransferase, gene polymorphisms, colorectal cancer, irinotecan-related toxicity

\section{UGT1A1 POLIMORFIZMI KAO PREDIKTIVNI FARMAKOGENETIČKI BILJEZI IRINOTEKANSKE TOKSIČNOSTI U BOLESNIKA S METASTATSKIM KOLOREKTALNIM KARCINOMOM}

\section{Sažetak}

Cilj ovog rada je bio napraviti pregled trenutnog statusa UGT1A1 polimorfizama kao farmakogenetičkih biljega za predviđanje toksičnosti na irinotekansku kemoterapiju u bolesnika s metastatskim kolorektalnim karcinomom. Nedostatci $\mathrm{u}$ aktivnosti uridin-difosfat-glukuronoziltransferaze (UGT) su uglavnom zbog polimorfizama gena i mogu dovesti do povećane izloženosti irinotekanu i njihovom aktivnom metabolitu uzrokujući ozbiljne, ponekad životno ugrožavajuće nus- 
pojave. Iako podatci sugeriraju da su UGT1A1 polimorfizmi, posebice homozigoti (UGT1A1*28/*28, UGT1A1*6/*6), povezani s ozbiljnim irinotekanskim nuspojavama i neke smjernice ističu značaj genotipizacije UGT1A1 prije početka liječenja irinotekanom u svrhu davanja sigurnije doze irinotekana, UGT1A1 genotipizacija se trenutno rutinski ne provodi u kliničkoj praksi.

Važno je naglasiti da UGT1A1 genski polimorfizmi pokazuju etničke razlike te se preporuča da se bijelci testiraju na UGT1A1*28, a azijati na UGT1A1*6 s obzirom da su ti polimorfizmi najčeće genske varijacije u tim populacijama. Podatci o povezanosti UGT1A1 polimorfizama i odgovora na terapiju i preživljenje su proturječni. Također je bitno misliti i na druge genetske varijacije u kontekstu kemoterapijom-inducirane toksičnosti, posebice nedostatka enzima dihidropirimidin dehidrogenaze.

U zaključku, UGT1A1 polimorfizmi su farmakogenetički biljezi koji bi se mogli koristiti za izdvajanje pacijenata koji su pod većim rizikom za razvijanje irinotekanom-inducirane toksičnosti i omogućiti im preventivno smanjenje doze u svrhu smanjenja potencijalne toksičnosti.

KLJUČNE RIJEČI: uridin-difosfat-glukuronoziltransferaza, genski polimorfizmi, kolorektalni karcinom, irinotekanom izazvane nuspojave

\section{INTRODUCTION}

Colorectal cancer (CRC) is the third most common cancer in men $(746,000$ cases, $10.0 \%$ of the total) and the second in women $(614,000$ cases, $9.2 \%$ of the total) worldwide (1). The overall survival of patients with metastatic CRC has increased to approximately 3 years with current therapy (2). Treatment options for CRC are dependent on the stage of the disease, tumor biology, patients general condition, comorbidities, previous therapy and their wishes. Chemotherapy-induced toxicities are very important factor because they can restrict the clinical application of chemotherapy.

Irinotecan is a topoisomerase 1 inhibitor, it binds to the DNA/topoisomerase I complex during DNA replication, preventing the resealing of single-strand breaks. Irinotecan is a cornerstone chemotherapy agent for the first-line treatment of metastatic colorectal cancer ( $\mathrm{mCRC}$ ) together with 5-fluorouracil (5-FU) and oxaliplatin with the addition of targeted therapy according to NRAS/ KRAS/BRAF status; epidermal growth factor receptors (EGFR) inhibitors cetuximab/panitumum$\mathrm{ab}$ or anti-vascular endothelial growth factor (VEGF) bevacizumab $(2,3)$.

Irinotecan is usually co-administered with infusional 5-fluorouracil/leucovorin (FOLFIRI regimen), with the addition of targeted therapies, as a front line for patients with metastatic colorectal cancer. Irinotecan treatment has an acceptable safety profile in most patients, but up to $35 \%$ of patients treated with combination regimens of 5-FU and irinotecan experience clinically relevant treatmentrelated toxicities, mainly diarrhea, stomatitis and myelosuppression $(4,5)$. The number of clinically relevant treatment-related toxicities increases sig- nificantly, up to $35-50 \%$, with the intensification of the treatment using triplet regimen (FOLFOXIRI; $5-\mathrm{FU}$, oxaliplatin and irinotecan) $(6,7)$.

Irinotecan is converted into its active form 7-ethyl-10-hydroxycamptothecin (SN-38) by a carboxylsterase and inactivated through uridine diphosphate glucuronosyltransferase (UGT1A1). Several isoforms of UDP-glucuronosyltransferase (UGT) enzyme are responsible for hepatic bilirubin glucuronidation (8). The glucuronidation of an active form of irinotecan (SN-38) is catalyzed by UGT1A1, UGT1A3, UGT1A6 and UGT1A9, but UGT1A1 has the highest activity. Thus, reduced UGT1A1 expression can affect on irinotecan metabolism and lead to increased risk of irinotecan associated toxicity (8).

Genetic variations within the UGT1A1 gene, known as polymorphisms, can lead to decreased enzyme activity and are associated with a higher risk of severe toxicity with irinotecan, such as neutropenia and diarrhea. UGT1A $1^{*} 1$ is a common variation with six TA repeats in promoter region while the seven-repeat variant UGT1A1*28is responsible for a dramatically reduced expression of UGT1A1 causing an increase in adverse events due to poor metabolism of the SN38 active metabolite of irinotecan $(9,10)$. UGT1A1*28 homozygote genotype was found in less than $10 \%$ of the Croatian population (11). UGT1A $1^{*} 6$, a nonsynonymous single nucleotide polymorphism (SNP) in exon 1, was frequently found in an Asian population (12).

\section{Clinical significance of UGT1A1 gene polymorphisms}

Clinically relevant, dose-limiting irinotecanrelated toxicities include myelosuppression diarrhea and dehydration (13). Several meta-analy- 
ses were conducted to asses the association of UGT1A1 gene polymorphisms and the occurrence of irinotecan-related severe neutropenia and diarrhea. Majority of them included other tumor sites beside CRC (14-19). Other limitations were the inclusion of patients who were treated with different chemotherapy protocols, different doses of irinotecan, different polymorphism detection methods were used across studies (14-20). The most relevant meta-analysis from Liu et al. assessing the association of UGT1A1 gene polymorphisms and irinotecan-induced neutropenia and diarrhea included only patients with CRC. It showed more than fourfold (OR 4.79, 95\% CI 3.28$7.01 ; \mathrm{P}<0.00001)$ increase in the risk of neutropenia for UGT1A1*1/*28 genotype, and twofold (OR 1.90, 95\% CI: 1.44-2.51; $\mathrm{P}<0.00001)$ increase in the risk of neutropenia for UGT1A1*1/*28 genotype, compared to UGT1A $1 * 1 /{ }^{*} 1$. The risk of diarrhea was around twofold increased (OR 1.84, 95\% CI 1.24-2.72; $\mathrm{P}<0.002)$ for UGT1A1*28 homozygous patients compared to UGT1A $1 * 1 /{ }^{*} 1$ (20).

Conflicting data were published regarding the association of UGT1A $1^{*} 28$ polymorphisms and response to chemotherapy and survival outcomes (21-26). Recent Liu et al meta-analysis showed that UGT1A1*28 polymorphisms were associated with a higher response among patients with metastatic colorectal cancer (OR 1.24, 95\%CI 1.05-1.48) compared to UGT1A1*1/*1 (19).

A dose of irinotecan seems to be relevant for irinotecan-related toxicities. Metaanalysis from $\mathrm{Hu}$ et al. showed no association between UGT1A1*28 genotype and severe diarrhea treated with low doses of irinotecan $(<125 \mathrm{mg} / \mathrm{m} 2)$ (RR $0.65,95 \%$ CI $0.27-1.58$ ), while the risk of severe diarrhea was significantly higher for patients with UGT1A1*28 genotype treated with medium or high irinotecan doses (OR 1.79, 95\% CI 1.08-2.97 - medium dose, OR 2.32 95\% CI 1.25-4.28 - high dose) (15). In subgroup meta-analysis of Liu et al. also showed higher incidence of diarrhoea in UGT1A1*28/*28 patients treated with higher dose of irinotecan $(>150 \mathrm{mg} / \mathrm{m} 2)(\mathrm{OR}=2.37,95 \% \mathrm{CI}: 1.39$ 4.04; $\mathrm{P}=0.002$ ) while patients with $\mathrm{UGT} 1 \mathrm{~A} 1{ }^{*} 1 /{ }^{*} 28$ genotype had slightly increased risk (OR 1.39, 95\% CI: 0.97-1.98; P 1/4 0.07) of borderline significance (20).

Hoskins et al suggested that association between UGT1A1*28 genotype and neutropenia is dose-dependent and that it had no effect on patients treated with low dose of irinotecan $(<150$ $\mathrm{mg} / \mathrm{m} 2$ ) while on the other hand, Hu et al found that UGT1A1*28/28* genotype was associated with an increased risk of neutropenia even at low doses (RR 2.43 - low dose $<150 \mathrm{mg} / \mathrm{m} 2$, RR 2.00 medium-dose $150-250 \mathrm{mg} / \mathrm{m} 2$, RR 7.22 high dose $>250 \mathrm{mg} / \mathrm{m} 2)(16,18)$.

In a trial designed to define the maximum tolerated dose according to UGT1A1 genotype maximum tolerable dose in patients with UGT1A1 $* 28 /{ }^{*} 28$ genotype was found to be $30 \%$ lower than the standard dose of $180 \mathrm{mg} / \mathrm{m} 2$ (27).

There are concerns that reduced dose will not be equally effective, and an open question whether patients with UGT1A $1 * 28 * 28$ genotype should be treated with other chemotherapeutic regimens which would be more suitable and effective for them (5).

A recent study from Fujii et al. showed that incidence rates of hematological as well as nonhematological toxicities were not significantly different among patients with different UGT1A1 polymorphisms when the initial dose of irinotecan was reduced by $20 \%$ in patients with homozygous mutations. The study also showed that the reduction in the initial dose of irinotecan by $20 \%$ in $\mathrm{mCRC}$ patients with homozygous mutations in UGT1A1 genes did not impair efficacy of chemotherapy containing irinotecan (28).

\section{Current status of UGT1A1 gene polymorphism screening}

Genetic polymorphisms of UGT1A1 show ethnic differences. It is reported that UGT1A1*28 occurs with a frequency of $0.26-0.31$ in Caucasians, 0.42-0.56 in African Americans, and 0.090.16 in Asian populations, while UGT1A1*6 has allele frequencies of around 0,2 for Asian population (29-31).

Several meta-analyses in Asian-only patients showed a lesser association between UGT1A ${ }^{*} 28$ compared to UGT1A1* 6 genotype and irinotecaninduced neutropenia, suggesting that UGT1A1*6 genotype could be a good predictor of irinotecaninduced toxicity in this population $(16,17)$. It is recommended that Caucasian patients should be upfront screened for UGT1A1*28 and Asian patients for UGT1A1* 6 as these polymorphisms are common genetic variation in these populations (32). Both of these polymorphisms can result in approximately 70\% reduction of UGT1A1 activity in carriers causing increased systemic exposure to 
irinotecan and SN-38 in homozygous patients for these variants and increase the risk of irinotecanrelated toxicities (32).

Current FDA recommendation regarding dose reduction in patients homozygous for the UGT1A1*28 allele receiving irinotecan is not precise. The Dutch Pharmacogenetics Working Group (DPWG) of the Royal Dutch Association for the Advancement of Pharmacy (KNMP) recommends starting with $30 \%$ reduced dose for homozygous carriers of the UGT1A1*28 allele with the possibility to increase the dose if well tolerated, guided by the neutrophil count. Also stating that no action is needed for heterozygous carriers of the UGT1A1*28 allele. French National Network of Pharmacogenetics (RNPGx) has dose-dependent recommendation stating that presence of the UGT1A1*28 allele is not a major risk factor for patients treated with lower doses of irinotecan $(<180 \mathrm{mg} /$ $\mathrm{m} 2)$, at medium doses $(180-230 \mathrm{mg} / \mathrm{m} 2) 25-30 \%$ dose reduction is recommended for patients homozygous for the UGT1A1*28 allele, while the administration of irinotecan at this higher dose $(>230$ $\mathrm{mg} / \mathrm{m} 2$ ) is contraindicated for homozygous for the UGT1A $1^{*} 28$ allele and leading to discussion of a standard dose depending on the associated risk factors. High dose of irinotecan $(240 \mathrm{mg} / \mathrm{m} 2)$ is recommended only for ${ }^{*} 1 /{ }^{*} 1$ patients, or for heterozygous UGT1A1*28 patients who have no other risk factors and who benefit from intensive surveillance (33-36).

Current NCCN guidelines state that although commercial tests are available to detect the UGT1A1*28 allele guidelines for use of this test in clinical practice have not been established. Furthermore, UGT1A1 testing on patients who experienced irinotecan toxicity is not recommended, as they will require a dose reduction regardless of the UGT1A1 test result (3). Therefore, the adoption of an upfront UGT1A1*28 genotyping to increase irinotecan safety in clinical practice is still limited and currently not routinely performed (32).

The patient safety and clinical outcomes could be substantially improved by upfront UGT1A1 screening and UGT1A1- guided dose individualization to predict, diminish and even avoid toxicity to improve the therapeutic effect of irinotecan (5).

The recent cost-effective analysis showed that the costs of the management of irinotecan-related toxicity are significantly higher in patients carrying either a ${ }^{*} 28 /{ }^{*} 28$ or a ${ }^{*} 1 / * 28$, as compared to ${ }^{*} 1 /{ }^{*} 1$ genotype. The cost of all toxicities management per patient increased 1.4 folds for $* 1 /{ }^{*} 28$ carriers in comparison to ${ }^{*} 1 /{ }^{*} 1$, and 6 -fold for the *28/*28 patients (37).

\section{Other pharmacogenetic markers for CRC chemotherapy-related toxicity}

Irinotecan has a toxicity profile which overlaps with those of fluoropyrimidines (5-fluorouracil and capecitabine). Dihydropyrimidine dehydrogenase (DYPD) gene encodes for the enzyme dihydropyrimidine dehydrogenase (DPD), which is important for the metabolism of fluoropyrimidines and de-activates more than $80 \%$ of administered fluoropyrimidine. Factors such as age, race, comorbidities, and concomitant therapies also influence metabolism (38).

Reduced or absent activity of this enzyme in DYPD deficient patients can result in severe and sometimes fatal toxicity; severe and prolonged pancytopenia, sometimes associated with sepsis, serious gastrointestinal toxicity with refractory diarrhea and dehydration, severe mucositis and severe skin changes (39-41). There are numerous genetic variants in DPYD, but four DPYD variants causing decreased function were shown to be important for patients treated with fluoropyrimidines: c.1905+1G>A (rs3918290, also known as DPYD*2A, DPYD:IVS14 + 1G>A), c.1679T>G (rs55886062, DPYD *13, p.I560S), c.2846A>T (rs67376798, p.D949V), and c.1129-5923C $>$ G (rs75017182, HapB3). Among those c. 1905+1G>A and c. $1679 \mathrm{~T}>\mathrm{G}$ have the most deleterious impact on DPD activity (40).

Around $\sim 7 \%$ of Europeans carry at least one decreased function DPYD variant. The most common is c. $1129-5923 C>G$ decreased function DPYD variant with carrier frequencies of $4.1-4.8 \%$, while carrier frequency for c. $1905+1 \mathrm{G}>\mathrm{A}$ is much rarer, $1-1.2 \%(40)$.

Currently upfront DPYD genotyping remains controversial, as it is the case with UGT1A1 genotyping.

Furthermore, other genetic variation including the carboxylesterase 1 (CES1) gene, the multidrug resistance-associated protein 2 (MRP2) gene, and organic anion-transporter family, member 1B1 (OATP1B1; SLCO1B1) gene, are suggested to be associated with interindividual variability in 
the pharmacokinetics and subsequently with toxicity to irinotecan (12).

\section{CONCLUSION}

Irinotecan is a crucial component of chemotherapy regimens for the treatment of metastatic colorectal cancer. UGT1A1 polymorphisms can cause a reduction in enzymatic activity that can induce severe, sometimes life-threatening toxicities with a standard dose of irinotecan. Therefore, using UGT1A1 polymorphisms would be beneficial with the rationale to personalize the dosing of irinotecan according to UGT1A1 genotype status to reduce toxicities and optimize treatment effect, although its use as an upfront screening to increase irinotecan safety is still limited and currently not routinely performed in the daily clinical practice.

\section{REFERENCES}

1. GLOBOCAN 2012: Estimated Cancer Incidence, Mortality and Prevalence Worldwide in 2012. http://globocan.iarc.fr/Pages/fact_sheets_cancer.aspx. Accessed on $3^{\text {rd }}$ June 2019.

2. Sveen A, Kopetz S, Lothe RA. Biomarker-guided therapy for colorectal cancer: strength in complexity. Nat Rev Clin Oncol. 2019 Jul 9. doi: 10.1038/s41571-0190241-1.

3. National Comprehensive Cancer Network. (2019). Colon cancer (version 2.2019). Retrieved from https:// www.nccn.org/professionals/physician_gls/pdf/colon.pdf. Accessed on $3^{\text {rd }}$ June 2019.

4. Fuchs CS, Melvin RM, Harker G et al. Phase III comparison of two irinotecan dosing regimens in secondline therapy of metastatic colorectal cancer. J Clin Oncol. 2003;21(5):807-14.

5. Páez D. Genetics and adverse events with irinotecan treatment: what do we know? Pharmacogenomics. 2019;20(6):393-395. doi: 10.2217/pgs-2019-0012.

6. Falcone A, Ricci S, Brunetti I, Pfanner E, Allegrini G, Barbara C, Crinò L, Benedetti G, Evangelista W, Fanchini L, Cortesi E, Picone V, Vitello S, et al, and Gruppo Oncologico Nord Ovest. Phase III trial of infusional fluorouracil, leucovorin, oxaliplatin, and irinotecan (FOLFOXIRI) compared with infusional fluorouracil, leucovorin, and irinotecan (FOLFIRI) as firstline treatment for metastatic colorectal cancer: the Gruppo Oncologico Nord Ovest. J Clin Oncol. 2007; 25:1670-1676.

7. Loupakis F, Cremolini C, Masi G, Lonardi S, Zagonel V, Salvatore L, Cortesi E, Tomasello G, Ronzoni M, Spadi R, Zaniboni A, Tonini G, Buonadonna A, et al. Initial therapy with FOLFOXIRI and bevacizumab for metastatic colorectal cancer. N Engl J Med. 2014;371: 1609-1618.

8. Innocenti F, Ratain MJ. Irinotecan treatment in cancer patients with UGT1A1 polymorphisms. Oncology (Williston Park) 2003;17(5 Suppl. 5):52-55.

9. Liu X, Cheng D, Kuang Q, Liu G, Xu W. Association of UGT1A1*28 polymorphisms with irinotecan-induced toxicities in colorectal cancer: a meta-analysis in Caucasians. Pharmacogenomics J. 2014;14:120-129.

10. Cremolini C, Del Re M, Antoniotti C, Lonardi S, Bergamo $\mathrm{F}$, Loupakis $\mathrm{F}$ et al. DPYD and UGT1A1 genotyping to predict adverse events during first-line FOLFIRI or FOLFOXIRI plus bevacizumab in metastatic colorectal cancer. Oncotarget. 2017;9(8):7859-7866. doi:10.18632/oncotarget.23559

11. Marinković N, Pasalić D, Grsković B, Ferencak G, Honović L, Rukavina AS. Genotype frequencies of UDP-glucuronosyltransferase 1A1 promoter gene polymorphism in the population of healthy Croatian pre-scholars. Coll Antropol. 2008;32(3):725-729.

12. Onoue M Terada T, Kobayashi M, Katsura T, Matsumoto S, Yanagihara K et al. UGT1A1*6 polymorphism is most predictive of severe neutropenia induced by irinotecan in Japanese cancer patients. Int J Clin Oncol. 2009;14(2):136-142.

13. Package Insert. Camptosar ${ }^{\circledR}$ (irinotecan hydrochloride injection). New York, NY: Pfizer, Inc.; 2014. Available at: http://www.accessdata.fda.gov/drugsatfda docs/label/2014/020571s048lbl.pdf. Accessed on $3^{\text {rd }}$ June 2019.

14. Han FF, Guo CL, Yu D, Zhu J, Gong LL, Li GR, et al. Associations between UGT1A1* 6 or $\mathrm{UGT}^{\mathrm{AA}} 1^{*} 6 / 28$ polymorphisms and irinotecan-induced neutropenia in Asian cancer patients. Cancer Chemother Pharmacol. 2014;73(4):779-88.

15. Hu ZY, Yu Q, Zhao YS. Dose-dependent association between UGT1A ${ }^{*} 28$ polymorphism and irinotecaninduced diarrhoea: a meta-analysis. Eur J Cancer. 2010;46(10):1856-65.

16. Hu ZY, Yu Q, Pei Q, Guo C. Dose-dependent association between UGT1A1*28 genotype and irinotecaninduced neutropenia:low doses also increase risk. Clin Cancer Res. 2010;16(15):3832-3842.

17. Chen Y, Hu F, Li CY, Fang JM, Chu L, Zhang X, et al. The association of UGT1A1* 6 and UGT1A1*28 with irinotecan induced neutropenia in Asians: a metaanalysis. Biomarkers. 2014;19(1):56-62.

18. Hoskins JM, Goldberg RM, Qu P, Ibrahim JG, McLeod HL. UGT1A1*28 genotype and irinotecan-induced neutropenia: dose matters. J Natl Cancer Inst. 2007; 99(17):1290-1295.

19. Liu XH, Lu J, Duan W, Dai ZM, Wang M, Lin S et al. Predictive Value of UGT1A1*28 Polymorphism In Irinotecan-based Chemotherapy. J Cancer. 2017;8(4): 691-703.

20. Liu X, Cheng D, Kuang Q, Liu G, Xu W. Association of UGT1A ${ }^{*} 28$ polymorphisms with irinotecan-induced 
toxicities in colorectal cancer: a meta-analysis in Caucasians. Pharmacogenomics J. 2014;14(2):120-9.

21. Yu Q, Zhang T, Xie C, Qiu H, Liu B, Huang L et al. UGT1A polymorphisms associated with worse outcome in colorectal cancer patients treated with irinotecan-based chemotherapy. Cancer Chemother Pharmacol. 2018 ;82(1):87-98. doi: 10.1007/s00280-018-3595-7.

22. Xu C, Tang X, Qu Y, Keyoumu S, Zhou N, Tang Y. UGT1A1 gene polymorphism is associated with toxicity and clinical efficacy of irinotecan-based chemotherapy in patients with advanced colorectal cancer. Cancer Chemother Pharmacol. 2016;78(1):119-130. doi: 10.1007/s00280-016-3057-z.

23. Shulman K, Cohen I, Barnett-Griness O, Kuten A, Gruber SB, Lejbkowicz $\mathrm{F}$ et al. Clinical implications of UGT1A1*28 genotype testing in colorectal cancer patients. Cancer. 201;117(14):3156-3162. doi: 10.1002/ cncr.25735.

24. Toffoli G, Cecchin E, Corona G, Russo A, Buonadonna A, D'Andrea $M$ et al. The role of UGT1A1*28 polymorphism in the pharmacodynamics and pharmacokinetics of irinotecan in patients with metastatic colorectal cancer. J Clin Oncol. 2006;24(19):3061-3068.

25. Dias MM, Sorich MJ, McKinnon RA. Impact of the UGT1A1*28 allele on response to irinotecan: A systematic review and meta-analysis. Pharmacogenomics 2012;13:889-899.

26. Dias MM, Pignon JP, Karapetis CS et al. The effect of the UGT1A1*28 allele on survival after irinotecanbased chemotherapy: a collaborative meta-analysis. Pharmacogenomics J. 2014;14(5): 424-431.

27. Marcuello E, Páez D, Paré L, Salazar J, Sebio A, del Rio $E$ et al. A genotype-directed phase I-IV dose-finding study of irinotecan in combination with fluorouracil/ leucovorin as first-line treatment in advanced colorectal cancer. Br J Cancer. 2011;105(1):53-7. doi: 10.1038/ bjc.2011.206.

28. Fujii H, Yamada Y, Watanabe D, et al. Dose adjustment of irinotecan based on UGT1A1 polymorphisms in patients with colorectal cancer. Cancer Chemother Pharmacol. 2019;83(1):123-129. doi: 10.1007/s00280018-3711-8

29. Beutler E, Gelbart T, Demina A. Racial variability in the UDP-glucuronosyltransferase 1 (UGT1A1) promoter: a balanced polymorphism for regulation of bilirubin metabolism? Proc Natl Acad Sci USA. 1998; 95:8170-8174.

30. Hall D, Ybazeta G, Destro-Bisol G, Petzl-Erler ML, Di Rienzo A. Variability at the uridine diphosphate glucuronosyltransferase 1A1 promoter in human populations and primates. Pharmacogenetics. 1999;9:591-599.

31. Barbarino JM, Haidar CE, Klein TE, Altman RB. PharmGKB summary: very important pharmacogene information for UGT1A1. Pharmacogenet Genomics. 2014;24(3):177-183.

32. de Man FM, Goey AKL, van Schaik RHN, Mathijssen $\mathrm{RHJ}$, Bins S. Individualization of Irinotecan Treat- ment: A Review of Pharmacokinetics, Pharmacodynamics, and Pharmacogenetics. Clin Pharmacokinet. 2018;57(10):1229-1254.

33. Dean L. Irinotecan Therapy and UGT1A1 Genotype. 2015 May 27 [Updated 2018 Apr 4]. In: Pratt V, McLeod H, Rubinstein W, et al., editors. Medical Genetics Summaries [Internet]. Bethesda (MD): National Center for Biotechnology Information (US); 2012-. Available from: https://www.ncbi.nlm.nih.gov/books/ NBK294473/ Accessed on 15 ${ }^{\text {th }}$ February 2019.

34. IRINOTECAN HYDROCHLORIDE- irinotecan hydrochloride injection [package insert]. Orlando, FL, USA. Available from: https://dailymed.nlm.nih.gov/ dailymed/drugInfo.cfm?setid=d04f2471-3085-4fc8a657-bb3918d48e6eu. Accessed on $15^{\text {th }}$ February 2019.

35. Royal Dutch Pharmacists Association (KNMP). Dutch Pharmacogenetics Working Group (DPWG). Pharmacogenetic Guidelines [Internet]. Netherlands. Irinotecan - UGT1A1. Available from: http://kennisbank. knmp.nl. Accessed on $15^{\text {th }}$ February 2019.

36. Quaranta S, Thomas F. Pharmacogenetics of anti-cancer drugs: State of the art and implementation - recommendations of the French National Network of Pharmacogenetics. Therapie. 2017;72(2):205-215.

37. Roncato R, Cecchin E, Montico M, De Mattia E, Giodini L, Buonadonna A et al. Cost Evaluation of Irinotecan-Related Toxicities Associated With the UGT1A1*28 Patient Genotype. Clin Pharmacol Ther. 2017 Jul;102(1):123-130. doi: 10.1002/cpt.615.

38. Murphy C, Byrne S, Ahmed G, Kenny A, Gallagher J, Harvey $\mathrm{H}$ et al. Cost Implications of Reactive Versus Prospective Testing for Dihydropyrimidine Dehydrogenase Deficiency in Patients With Colorectal Cancer: A Single-Institution Experience. Dose Response. 2018; 16(4):1559325818803042.doi:10.1177/1559325818803042.

39. Van Kuilenburg AB, Baars JW, Meinsma R, van Gen$\operatorname{nip} \mathrm{AH}$ : Lethal 5-fluororacil toxicity associated with a novel mutation in the dihydropyrimidine dehydrogenase gene. Ann Oncol. 2003;14(2): 341-342.

40. Amstutz U, Henricks LM, Offer SM, Barbarino J, Schellens JHM, Swen JJ et al. Clinical Pharmacogenetics Implementation Consortium (CPIC) Guideline for Dihydropyrimidine Dehydrogenase Genotype and Fluoropyrimidine Dosing: 2017 Update. Clin Pharmacol Ther. 2018;103(2):210-216. doi: 10.1002/cpt.911.

41. Ledić Drvar D, Juretić A, Štulhofer-Buzina D, Manola I. Cutaneous side effects of targeted therapy for colorectal carcinoma. Rad Hrvatske akademije znanosti i umjetnosti, 2015; (522=41), 169-180. Preuzeto s https://hrcak. srce.hr/139049. Accessed on $15^{\text {th }}$ February 2019.

Corresponding author: Petra Vuković, Division of Radiotherapy and Medical Oncology, University Hospital for Tumors, Sestre milosrdnice University Hospital Center, Ilica 197, 10000 Zagreb, Croatia. e-mail: petravukovic13@gmail.com 